\title{
Hour Times Micromole per Milliliter
}

National Cancer Institute

\section{Source}

National Cancer Institute. Hour Times Micromole per Milliliter. NCI Thesaurus. Code C85618.

Hours times micromoles per milliliter. 